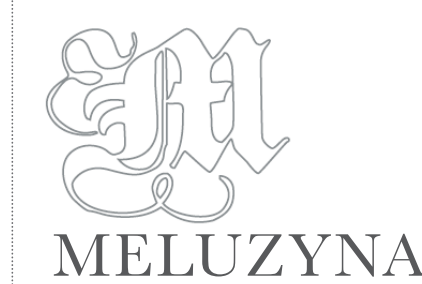

ISSN 2449-7339

1 (12) (2020) I Rocznik VII

DOI: 10.18318/me.2020.1-01

PRZEKROJE I ZBLIŻENIA

Natalia Tukiendorf ${ }^{\star}$

Uniwersytet Marii Curie-Skłodowskiej

ORCID 0000-0002-2482-2573

\title{
Ponadwyznaniowy charakter traktatu Stadło małżeńskie Jana Płoczywłosa Mrowińskiego
}

Jan Płoczywłos Mrowiński (1514-1580) jest ciekawą postacią wśród polskich pisarzy. Świadczy o tym już dedykacja Stadła małżeńskiego, w której autor - szlachcic herbu Jelita - identyfikuje się jako „mieszczanin kazimierski” (Mrowiński, 1890, s. 1). Był nie tylko szlachcicem „wrosłym” w podkrakowski Kazimierz, ale też burmistrzem i rajcą tego miasta, choć - jak wiadomo piastowanie przez herbowego urzędów miejskich skutkowało utratą szlachectwa (Celichowski, 1890, s. IV-V). Mrowiński zmarł jako katolik, a w krużganku kościoła św. Katarzyny na Kazimierzu w Krakowie zachował się piękny i niezwykły nagrobek autora Stadła..., na którym wyobrażono go trzymającego na kolanach kapelusz. Nie jest znana jego przynależność konfesyjna w latach sześćdziesiątych XVI wieku (Bieniarzówna, 1977, s. 197).

Traktat, opublikowany w Krakowie w 1561 roku w oficynie wydawniczej Łazarza Andrysowi$\mathrm{cza}^{1}$, jest inspirowany Biblią, stanowi też swoistą syntezę poglądów starożytnych autorów (m.in. Likurga, Platona, Arystotelesa - twórca wymienia ich w marginaliach) i też pisarzy religijnych różnych wyznań, co Mrowiński zaznacza w tytule: Stadło małżeńskie, z gron a ziarnek Słowa Bożego i z Autorów zacnych krótko zebrane, a na polską mowę wyłożone. Nigdzie jednak nie pada deklaracja konfesyjna, która bez wątpliwości wskazywałaby, że czytelnik ma do czynienia

\footnotetext{
* e-mail autorki: n.tukiendorf@o2.pl

1 Unikat przechowywany w Bibliotece Kórnickiej, sygn. Cim.O.205.
} 
z dziełem katolika bądź protestanta. Także adresat traktatu pozostaje nieokreślony wyznaniowo. Stadło małżeńskie nie spełnia kryteriów książki formacyjnej - brak w nim zideologizowanego i zinstytucjonalizowanego przekazu, który byłby jednoznaczny konfesyjnie (Winiarska-Górska, 2015, s. 133-137). Jednak Mrowiński zaczerpnął wiele wątków z luterańskiej książki formacyjnej, jaką jest Oeconomia, albo Gospodarstwo (1545). Ten poświęcony małżeństwu i życiu rodzinnemu traktat został wydany w Królewcu - stolicy pierwszego luterańskiego państwa w Europie, ważnym ośrodku polskiego ruchu wydawniczego i kulturalnego. Zapożyczanie się kazimierskiego rajcy w Oeconomii ma swoją wagę - niedawno wykazano, że ten anonimowy (sygnowany inicjałami S.S.) traktat z Królewca stanowi tłumaczenie, nieznacznie tylko wzbogacone o polskie wątki, dzieła Oeconomia christiana, das ist Von christlicher Haushaltung (1529) autorstwa Justusa Meniusa, który był bliskim współpracownikiem Marcina Lutra (Chemperek, 2020, s. 71-77).

W dobie renesansu toczono tzw. spór o kobiety (dyskusja zwana querelle des femmes), co wpłynęło na zmiany w ukazywaniu ich obrazu i roli w społeczeństwie ${ }^{2}$. Głos zabrali m.in. Francesco Petrarca, Pietro Bembo, Agnolo Firenzuola, Galeazzo Flavio Capra, Andrzej Glaber z Kobylina czy Henryk Korneliusz Agryppa, którzy należeli do obrońców niewiast (Łukasiewicz-Chantry, 2011, s. 157; Bogucka, 2005, s. 115-144; Wojtkowska-Maksymik, 2008, s. 89-90; Partyka, 2004, s. 36-37). Dzieło O szlachetności a zacności płci niewieściej autorstwa ostatniego z wymienionych stanowi jeden z wielu głosów we wspomnianym sporze. Odwołując się do słów Salomona, Agryppa twierdził, że dobra i stateczna żona jest darem od Pana Boga (Agrippa, 1891, s. 9), choć, jak zauważa współczesny badacz, zawartej w traktacie niemieckiego humanisty apologii kobiety bynajmniej nie można nazwać jednoznaczną3.

Podobnie ambiwalentne, choć zasadniczo aprobatywne twierdzenia na temat kobiet umieścił w swoim traktacie Mrowiński. Autor Stadła... skupia uwagę głównie na pochwale małżeństwa (choć zaznacza występowanie dwóch przypadków, w których nie jest ono stanem koniecznym: „przyrodzenie niedołężliwe albo anielskie życie” [Mrowiński, 1890, s. 27]). Podkreśla takie jego pożytki, jak wspieranie się małżonków i obopólny ratunek przed grzechem nieczystości, a ponadto przypomina, że jest ono ustanowione przez samego Boga (ok. XII-XIII wieku pierwsze summy teologiczne wskazywały na sakramentalność związku małżeńskiego [Tomasz z Akwinu, 1984, s. 13-20], lecz zostało ono uznane za sakrament dopiero podczas soboru trydenckiego [Gręźlikowski, 2003, s. 184]). Pojawianie się w traktacie z 1561 roku takich wątków, jak dowartościowanie erotyzmu czy aprobata małżeństw dwuwyznaniowych („iżeby stadło małżeńskie ani dla jakiej ckliwości, przyjaźni naruszenia, starości i szkaradości, niedołężliwości, ubóstwa, niepłodności, choroby, plugastwa albo jakiego zarażającego wrzodu, nadto ani dla różności wiary albo jakiego odszczepieństwa, na ostatek żadną mocą ludzką albo wymysłem rozerwano być mogło” [Mrowiński,

\footnotetext{
2 Prawo polskie w XVI wieku mówiło, że kobiety nie mogą być samodzielne ani w zakresie prawa sądowego, ani prywatnego - zob. Dąbkowski, 1920, s. 47. W prawie stanowym płeć zyskiwała istotną rangę - pełnię praw posiadali mężczyźni, kobiety były w tym względzie ograniczane. Ich niższa pozycja miała swoje korzenie w podległości mężczyźnie, jednak w prawie majątkowym kobietom przyznawano prawo do rzeczy ruchomych. Prawo dzielnicowe zwyczajowe głosiło, że płeć piękna może dziedziczyć i otrzymywać na własność dobra ziemskie. Prawnie zaopiekowano się wdowami - zakazano pozywania ich w okresie żałoby, a także traktowano ich przypadek jako osobne zagadnienie prawne. Dopiero XVII wiek przynosi powszechność prawa do dziedziczenia dóbr ojczystych przez kobiety (nie tylko w przypadku braku braci). Zob. Makkiła, 2013, s. 183-185.

3 O „profeministyczno-mizoginicznej dwoistości dzieła Agryppy” pisał Krzysztof Obremski (2012).
} 
1890, s. 5; podkreśl. N.T.]), świadczy o czerpaniu z koncepcji reformatorów, zwłaszcza Marcina Lutra. Można zatem postawić tezę o ponadwyznaniowym charakterze Stadła małżeńskiego.

Traktat ma klarowną, trójdzielną konstrukcję, skupioną wokół refleksji nad korzyściami płynącymi z małżeństwa. Według Mrowińskiego służy ono „dla ratunku zobópólnego [...] dla rozpłodzenia się Panu Bogu ku chwale, a rzeczypospolitej ku pożytku [...] dla zbawienia dusznego, bo się snadniej możem uwarować od grzechu nieczystego" (Mrowiński, 1890, s. 6). Wynika stąd jednoznaczny wniosek, że związek kobiety i mężczyzny jest lepszy od celibatu. Podobny sposób wartościowania małżeństwa odnaleźć można w Komedyi Justyna i Konstancyjej Marcina Bielskiego czy w Opisaniu pobożnej i statecznej żony i dobrej gospodyniej Erazma Otwinowskiego (Bielski, 2001, s. 99-185; Otwinowski, 1999, s. 90-94). We wszystkich tych utworach dostrzeże czytelnik wpływ poglądów Lutra, który głosił, że wyłącznie ludzie obdarzeni rzadkim darem bezwzględnej czystości mogą pozostawać w stanie bezżennym, naturalnym zaś stanem człowieka jest życie w związku małżeńskim (Chemperek, 2017, s. 285-286).

Mrowiński w swych rozważaniach koncentruje się na aspekcie społecznym i psychologicznym małżeństwa. Uwzględnienie wątku psychologicznego jest novum na gruncie polskim, ponieważ w wydanym szesnaście lat wcześniej w Królewcu traktacie Oeconomia, albo Gospodarstwo czytamy o dwóch celach małżeństwa, którymi mają być prokreacja i właściwe ukierunkowanie popędu seksualnego:

Dla dwojakiej rzeczy pan Bóg stadło małżeńskie ustawił. Pirwsza jest, iżbyśmy się cnotliwie mnożyli, a dziatki ku czci i ku chwale jego wychowywali, jako przykazał [...].

$[\ldots]$

Wtóra przyczyna, abyśmy się uwarowali grzechu nieczystego, według nauki Pawła świętego [...] (Seklucjan, 1890, s. 18-19).

Rajca kazimierski wskazuje na te względy, ale porusza też aspekt psychologiczny związku człowiek, jako istota towarzyska, potrzebuje partnera w życiu, aby być spełnionym, szczęśliwym.

W stosunku do Oeconomia Mrowiński idzie wszakże krok dalej: akcentuje, że małżeństwo jest jedynym godnym człowieka stanem - niezależnie od wieku i od zdolności prokreacyjnych małżonków. Mężczyzna w podeszłym wieku powinien wejść w związek dla własnego bezpieczeństwa i po to, by zaznać radości:

A przeto starcom a zgrzybiałym i tym, w których nie masz już możności rodzenia i nadzieje płodu, pozwolono a wolne jest małżeństwo, i owszem śmiem mówić, iż jest potrzebne, aby swoje lata już zeszłe i nachylone w towarzystwie a w kochaniu z miłą żoną swobodniej, weselej i też wdzięczniej wiedli, przezpieczniej skończyli (Mrowiński, 1890, s. 7).

Wątek ten ma charakter typowo protestancki - luterańskie rozumienie małżeństwa wskazuje na fakt, iż jest ono - jak cytuje Janusz Podzielny:

boskim i prawowitym związkiem mężczyzny i kobiety ustanowionym z nadzieją posiadania potomstwa lub przynajmniej w celu unikania nierządu i grzechu na chwałę Boga [podkreśl. N.T.]. Ostateczny jego cel stanowi posłuszeństwo Bogu, leczenie z grzechu, przyzywanie Boga, pragnienie, 
kochanie, wychowywanie potomstwa na chwałę Boga, mieszkanie z żoną w bojaźni Pańskiej oraz niesienie krzyża (cyt. za: Podzielny, 2010, s. 145) ${ }^{4}$.

Luter, odmiennie niż autorzy katoliccy, gloryfikujący dziewictwo, uważał małżeństwo za stan czystości, naturalny dla człowieka, uwzględniający jego seksualność (Luter, 2009, s. 140-141). Jeszcze dalej w apologii małżeństwa jako związku służącego uniknięciu samotności poszedł strasburski reformator Martin Bucer, który przesunął akcent z funkcji prokreacyjnej małżeństwa na towarzyską (MacCulloch, 2017, s. 648-649).

Traktat Mrowińskiego mieści również tezy inspirowane teologią kalwinizmu, dotyczące zawierania związku małżeńskiego pod przymusem: „Wszakże ku małżeństwu gwałtem żadny nie ma być przymuszan” (Mrowiński, 1890, s. 17). Miłość jest ważniejsza od ekonomicznego kontraktu rodziców, którzy mogą się nie zgadzać na związek ich dzieci, sprzeciwienie się rodzicom jest jednak lepsze od grzechu cudzołóstwa: „I dla tego boże przykazanie jest, aby miłość żeńska nad miłość rodziców, braciej, sióstr, wszytkich przyjaciół była przełożona” (Mrowiński, 1890, s. 17). Tożsame argumenty znajdziemy w wydanym rok wcześniej szkockim traktacie First Book of Discipline obowiązującym w Prezbiteriańskim Kościele Szkocji. Autor tej pracy uważa, że pociąg seksualny dwojga młodych ludzi do siebie nawzajem stanowi dzieło Boga, co oznacza, że dzieci mogą sprzeciwiać się rodzicom przy podejmowaniu decyzji dotyczących zawierania związku małżeńskiego. Co więcej, duchowny powinien stanąć po stronie młodych (MacCulloch, 2017, s. 619). Mrowiński jest podobnego zdania:

miłość szczyra nie jest poddana pod żadnego rozkazowanie i bogacze swemi skarby jej kupić nie mogą ani przełożeństwo ani żadna zwierzchność przymusić ani srogość żadna, ani spaniałość panów miłości odgrozić albo przystraszyć mogą; sama jest wolna, bo w duchu a w sercu jest, któremi sam Bóg tylko władnie [...] (Mrowiński, 1890, s. 17).

Autor podkreśla swą solidarność z młodymi i ideą miłości wolnej od uwarunkowań stanowych czy finansowych:

Przeto wielce grzeszą wszyscy takowi ojcowie, matki [...], którzy tylko na pożytek, na stanu poważność, na majętność, na imienie, także na posagi, na wiana oglądając się, a baczność mając nie dla cnót a potrzeb tych małżeńskich, które wyżej wspomieniono, przeciw rozkazaniu bożemu, któremu pierwsze i więtsze posłuszeństwo ma być niż rodziców, dobrowolne przyzwolenie synów albo córek swych odgrażając, przymuszają je w niewdzięczne a poniewolne małżeństwa [...] (Mrowiński, 1890, s. 17-18).

Twórca traktatu zaznacza również, że małżeństwo zostało stworzone w celu nie tylko rozmnażania się czy ratunku duszy, ale także zaspokajania potrzeb cielesnych. Argumentem na poparcie tej tezy są słynne słowa św. Pawła: „Lepiej jest bowiem żyć w małżeństwie, niż płonąć”

\footnotetext{
4 Por. Luter, 2000, s. 78: „stworzywszy osobno mężczyznę i niewiastę, rozumie się, nie dla rozpusty, lecz aby żyli razem, byli płodni, płodzili dzieci, żywili i wychowywali je na chwałę Bożą. [...] Pożycie małżeńskie nie jest więc żadną igraszką ani żartem, lecz rzeczą znakomitą, osłoniętą boską powagą".
} 
(1 Kor 7, 9)5. Odważne wskazanie na małżeńskie pożycie natychmiast przywodzi na myśl retorykę reformacyjną. Miłość sprawia, że małżonkowie są jednym ciałem i duszą: „A tak pilnie od pana Boga rozkazanie jest, iż jeden nic w żadnej sprawie czynić i prześpiać nie może okrom pozwolenia drugiego”; „żona swem ciałem nie władnie, ale mąż. Także mąż nie władnie swem ciałem, ale żona" (Mrowiński, 1890, s. 14, 15). Podobnie, choć oględniej, o małżeństwie jako wspólnocie pisał kilka lat później ewangelik reformowany Mikołaj Rej w Żywocie człowieka poczciwego:

Już przygoda, już choroba, już niedostatek każdy lżejszym być musi, niźli komu inemu, gdy już jedno drugiego onym wdzięcznym upominaniem cieszy, ratuje i, czym może, wspomaga. Już zawżdy dwoja radość i żałość dwoja po społu z sobą chodzi (Rej, 2003, s. 127).

Traktat Mrowińskiego zawiera także wątki charakterystyczne dla katolicyzmu. Przykładowo, jedną z aktywności zgodnego małżeństwa powinny być typowo katolickie praktyki postu czy nabożeństw roratnich:

A tak pilnie od pana Boga rozkazanie jest, iż jeden nic w żadnej sprawie czynić i prześpiać nie może okrom pozwolenia drugiego. Ani się modlić panu Bogu, na roraty chodzić, pościć, dawać jałmużny, acz to są zbawienne rzeczy [...] (Mrowiński, 1890, s. 14-15).

W istotnej wszakże kwestii, dotyczącej rozwodu, Mrowiński jest niejednoznaczny. Raz zgodnie z katolicką doktryną popiera nierozerwalność małżeństwa, by kilka słów dalej dopuszczać taką możliwość (jeśli dojdzie do cudzołóstwa):

Przeto dla żadnej przyczyny nie należy żenie od męża, mężowi od żony odstępować, wyjąwszy by samemu od siebie odstępić należało. Bo co z mężowej kości, z tegoż ciała toż ciało, taż kość z tychże kości, na ratunek mężowi stworzona, tej pan Bóg nie chce od męża być oddzielonej, albo jakim wymysłem oderwanej. Tylko dla cudzołóstwa, która jednaż sama przyczyna ta jest. Jeśliżeby dla innej jakiej przyczyny drugiej rozerwało się małżeństwo, chociaby byli rozwiedzeni prawem ludzkiem, przedsię sobie małżonkowie są i będą wedle bożego słowa (Mrowiński, 1890, s. 5-6).

W tym miejscu autor Stadła... kieruje się przeświadczeniem o sakramentalności związku małżeńskiego, podczas gdy dla Lutra czy Kalwina małżeństwo było instytucją świecką, choć świętą („marriage might not be a sacrament, but it was still sacred” [MacCulloch, 2017, s. 648]). Małżeństwo jest darem od Boga, Kościół czuwa nad partnerami, pomaga naprawiać związki, jednak „gdy uleczyć nie może, tedy miedzy dwiema rzeczami złemi, jednę jakoby lepszą obiera i zatwardziałe serce rozłącza, rozwodzi, rozwięzuje ciało ono, w którem dwie duszy, aby dusz nie straciła przykładem Mojżeszowym” (Mrowiński, 1890, s. 9). Autor powołuje się na przykład znany retoryce reformatorskiej (Stary Testament dopuszcza rozwód: „Jeśli mężczyzna poślubi kobietę i zostanie jej mężem, lecz nie będzie jej darzył życzliwością, gdyż znalazł u niej coś

5 Cytaty biblijne na podstawie: Zespół biblistów polskich (2003). 
odrażającego, napisze jej list rozwodowy, wręczy go jej, potem odeśle ją od siebie” [Pwt 24, 1]), zaznaczając przy tym, że nikt nie może przyczynić się do rozpadu związku - wyjątkiem jest rozdwojenie się go samo z siebie ze względu na niewierność partnera. Twarde, o katolickiej proweniencji, spojrzenie na tematykę rozwodu („dla którejkolwiek przyczyny albo potrzeby raz kto się uwiąże, już żadną mocą, żadnym fortelem nie może być rozwiązan” [Mrowiński, 1890, s. 15]), przeplata się więc z podejściem protestanckim.

Bardzo interesujący jest wzorzec osobowy kobiety nakreślony przez kazimierskiego rajcę. Nawiązując do opinii wypowiadanych w tzw. sporze o kobiety, dowartościowuje on rolę żony i matki; kobieta odzyskuje w Stadle małżeńskim indywidualność, pewną autonomię w związku. Aspekt ten w traktacie przedstawiony jest w podobnie ambiwalentny sposób, jak podejście do rozwodu. Żona winna być poddana mężowi, ale zarazem rządzić w domu wraz z nim (Mrowiński, 1890, s. 19). Mąż winien być „rozumem [...] przełożonym”, a żona mężowi „gospodynią [...] powolną" (Mrowiński, 1890, s. 19). To stanowisko tradycyjne', obok innego, również zaprezentowanego w Stadle...: „Abowiem nie z głowy są stworzone, ale z boku, aby nie były rzędochami, nie $\mathrm{z}$ nogi też, aby nie były w małej ważności u mężów, ale w środku, w mierze, nie jako pani, nie jako sługa też, ale środek, to jest jako towarzysz" (Mrowiński, 1890, s. 20). Kobieta - stworzona nie z głowy Adama, ani też nie z jego stopy - winna nie górować nad mężczyzną, ani też nie być przezeń niedoceniana. Mrowiński powiela tu koncept ucznia Lutra - Johannesa Mathesiusa (Chemperek, 2017, s. 286). Jednak mężczyzna, choć może czasem słuchać żony, jak partnerki - „Dla tego niekiedy też rady żeninej nie wadzi na czas słuchać [...]” (Mrowiński, 1890, s. 20) - co do zasady, nie powinien dawać jej pierwszeństwa.

Warto zaznaczyć, że obraz żony ukazany przez kazimierskiego rację jest podobny do wizerunku z Oeconomii, albo Gospodarstwa i zarazem z Oeconomia christiana Meniusa. Świadczy o tym obrazowe porównanie żony - domatorki, do żółwia:

Jako panią Wenus na żółwiu stojącą malowano tam na wyrozumienie dawając, że jako żółw swego domu nie opuszcza, tak też cnotliwa a pobożna matka domu swego nie ma opuszczać, ani żadnych spraw swych [...] (Seklucjan, 1890, s. 43).

Tak samo żona przedstawiona u Mrowińskiego winna na pierwszym miejscu zajmować się domem i rodziną: „ma naśladować żółwia (jako stara przypowieść jest), który z swojej szażuły nigdy nie wynijdzie" (Mrowiński, 1890, s. 20). To nie jedyne zapożyczenia z wcześniejszego traktatu. Kobieta, zdaniem autora Stadła..., winna stać się „matką czeladną” (s. 21) i takie jej określenia spotykamy też w Oeconomia (np. Seklucjan, 1890, s. 32).

Ojcowie i mężowie winni natomiast pracować zgodnie ze swoim powołaniem: „Ty też wedle wezwania twego pracej rąk twoich pożywając [...]. [...], aby nie był jako lew w domu, ale aby upominając, rozkazując nauczał jako ociec czeladny gospodarstwa" (Mrowiński, 1890, s. 19). W akapicie dotyczącym roli mężczyzny w rodzinie autor odwołuje się do luterańskiej idei pracy jako powoła-

\footnotetext{
6 Wielowiekowe traktowanie kobiet w sposób patriarchalny, wywodzący się z chrześcijańskiej tradycji, skutkowało odsunięciem ich od możliwości kształcenia się czy podejmowania samodzielnych decyzji; warto podkreślić także nakaz milczenia kobiet w kościele. Zob. Partyka, 2004, s. 33-35.
} 
nia. Także określenie „ociec czeladny” zostało zaczerpnięte z polskiej wersji traktatu Meniusa współpracownika reformatora $z$ Wittenbergi.

Mrowiński, podobnie jak Menius i jego polski tłumacz, nie idealizuje życia małżeńskiego: „ano lepiej białą farbę poznać, gdy czarną do niej przysadzi” (Mrowiński, 1890, s. 24). Mimo wszelkich wad związek winien trwać, ponieważ „co uchwyci każdy, musi dzierżeć” (Mrowiński, 1890, s. 24), nawet jeżeli negatywne cechy partnerki (np. zbytnia gadatliwość, plotkarstwo) odkryte zostały dopiero po ślubie.

Anonimowe tłumaczenie Oeconomia christiana pozwala na znalezienie pokrewieństw pomiędzy autorami (idąc wstecz): Jan Płoczywłos Mrowiński (1561) - polski tłumacz o inicjałach S. S. (1545) - Justus Menius (1529). Jak wykazała niniejsza analiza, oba polskie traktaty zostały oparte na naukach Lutra. Interesujące, że mimo obecności wielu wątków myślowych zaczerpniętych z teologii protestanckiej Stadło małżeńskie spotkało się, jak wolno sądzić, z aprobatywnym przyjęciem przez katolików. Świadczy o tym uznanie utworu Mrowińskiego za element inventio w Kazaniu o przyjmowaniu świętości małżeństwa pióra katolickiego biskupa Józefa Wereszczyńskiego (Sitkowa, 2019, s. 282-288).

Można założyć, iż autor Stadła... stosuje strategię nikodemizmu (MacCulloch, 2017, s. 267268), nie opowiadając się wprost po stronie reformacji, ale aplikując protestancką etykę i teologię do katolickiego rozumienia małżeństwa. Celem takiego zabiegu jest ukazanie innego spojrzenia na kwestię związku kobiety i mężczyzny. Na temat Mrowińskiego mamy dziś zbyt mało informacji, aby móc tę tezę bez wątpliwości potwierdzić. Wiadomo, że nie identyfikuje się on wprost z protestantyzmem, jednak zna tezy pisarzy ewangelickich i próbuje spleść niektóre $\mathrm{z}$ nich z tezami katolickimi. Stadło małżeńskie można traktować jako nowatorską propozycję połączenia etyki protestanckiej z nauką Kościoła rzymskiego.

\section{Bibliografia podmiotowa}

Agryppa, H.K. (1891). O ślachetności a zacności płci niewieściej. Kraków: Drukarnia C.K. Uniwersytetu Jagiellońskiego.

Bielski, M. (2001). Komedyja Justyna i Konstancyjej. Oprac., koment., wprowadz. J. Starnawski. Wstęp A. Gorzkowski. Kraków: Księgarnia Akademicka.

Luter, M. (2000). Mały katechizm - Duży katechizm. Przekł. A. Wantuła. Bielsko-Biała: Ośrodek Wydawniczy „Augustana”.

Luter, M. (2009). O życiu małżeńskim. Przeł. K. Toeplitz. W: M. Luter, Pisma etyczne (s. 139-160). Red. M. Hintz. Bielsko-Biała: Wydawnictwo „Augustana”.

Mrowiński, P.J. (1561). Stadło małżeńskie, z gron a ziarnek Słowa Bożego i z Autorów zacnych krótko zebrane, a na polska mowę wyłożone. Cracoviae: Lazarus Andreae excudebat. Pobrane z: http://www.wbc. poznan.pl/publication/27446 (10.05.2020). 
Mrowiński, P.J. (1890). Stadło małżeńskie, z gron a ziarnek Słowa Bożego i z Autorów zacnych krótko zebrane, a na polska mowe wyłożone. Kraków: Drukarnia Uniwersytetu Jagiellońskiego. Pobrane z: http://polona.pl/item/jana-mrowinskiego-ploczywlosa-stadlo-malzenskie-1561,MTY3NzU1NDY/ 20/\#info:metadata (11.05.2020).

Otwinowski, E. (1999). Pisma poetyckie. Wyd. P. Wilczek. Warszawa: Instytut Badań Literackich PAN. Rej, M. (2003). Żywot człowieka poczciwego. Oprac. J. Krzyżanowski: Wrocław: Ossolineum.

Seklucjan, J. (1890). Oeconomia, albo Gospodarstwo. Kraków: Drukarnia C.K. Uniwersytetu Jagiellońskiego. Pobrane z: http://www.wbc.poznan.pl/dlibra/publication/843/edition/1208/content (20.05.2020).

Tomasz z Akwinu, św. (1984). Suma teologiczna. T. 27: Sakramenty w ogóle, chrzest, bierzmowanie. Przeł., objaśn. P. Bełch. Londyn: Veritas. Pobrane z: http://www.katedra.uksw.edu.pl/suma/suma_32.pdf (9.09.2020).

Zespół biblistów polskich (oprac.) (2003). Pismo Święte Starego i Nowego Testamentu w przekładzie z języków oryginalnych. Z inicjatywy benedyktynów tynieckich. Wyd. 5. Poznań: Pallottinum.

\section{Bibliografia przedmiotowa}

Bieniarzówna, J. (1977). [hasło] Mrowiński. W: Polski słownik biograficzny (s. 197). T. 22. Wrocław: Polska Akademia Nauk.

Bogucka, M. (2005). Gorsza płeć. Kobieta w dziejach Europy od antyku po XXI wiek. Warszawa: Wydawnictwo „Trio”.

Celichowski, Z. (1890). Wstęp. W: P.J. Mrowiński (1890). Stadło małżeńskie, z gron a ziarnek Słowa Bożego i z Autorów zacnych krótko zebrane, a na polska mowę wyłożone (s. III-VI). Kraków: Drukarnia Uniwersytetu Jagiellońskiego. Pobrane z: http://polona.pl/item/jana-mrowinskiego-ploczywlosa-stadlo-malze nskie-1561,MTY3NzU1NDY/20/\#info:metadata (11.05.2020).

Chemperek, D. (2017). „Kalwińska święta”. Elżbiety z Szydłowieckich Radziwiłłowej ars bene vivendi w „Krótkim wypisaniu sprawy” Cypriana Bazylika. W: E. Buszewicz, L. Grzybowska (red.), Ars bene vivendi. Studia ofiarowane Profesorowi Maciejowi Włodarskiemu w 70. rocznicę urodzin (s. 273-290). Kraków: Wydawnictwo Uniwersytetu Jagiellońskiego.

Chemperek, D. (2020). Nowości z Królewca. Przypisywany Janowi Seklucjanowi pierwszy polski traktat o małżeństwie jako książka formacyjna. W: M. Barłowska, M. Walińska (red.), Sarmackie theatrum. T. 8: W poszukiwaniu nowości (s. 71-91). Katowice: Wydawnictwo Uniwersytetu Śląskiego.

Dąbkowski, P. (1920). Zarys prawa polskiego prywatnego. Podręcznik do nauki uniwersyteckiej. Lwów: K.S. Jakubowski.

Gręźlikowski, J. (2003). Czym był dla Kościoła Sobór Trydencki (1545-1563)? (refleksje w 440-tą rocznicę od zakończenia obrad). Prawo Kanoniczne 46 (3/4), 171-226.

Łukasiewicz-Chantry, M. (2011). Pramatka Ewa jako postać literacka w wybranych utworach renesansu. Italia, Niderlandy, Polska. Theologica Wratislaviensia, 6 (1), 157-169.

MacCulloch, D. (2017). Reformation: Europe's House Divided 1490-1700. London: The Folio Society.

Makiłła, D. (2013). Historia prawa w Polsce. Warszawa: Wydawnictwo Naukowe PWN.

Obremski, K. (2012). „Declamatio” jako retoryczna proto-dekonstrukcja piętnastowiecznej pochwały kobiet: Henryk Korneliusz Agryppa „O ślachetności a zacności płci niewieściej”. W: K. Obremski, 
Literatura staropolska czytana wspótczesną humanistyką. Przymiarki metodologiczne (s. 75-105). Toruń: Wydawnictwo Naukowe Uniwersytetu Mikołaja Kopernika.

Partyka, J. (2004). „Żona wyćwiczona”. Kobieta pisząca w kulturze XVI i XVII wieku. Warszawa: Instytut Badań Literackich PAN - Wydawnictwo.

Podzielny, J. (2010). Cele związku małżeńskiego według Marcina Lutra. Rocznik Teologii Ekumenicznej, 2 (1), 145-155.

Sitkowa, A. (2019). O inwencyjnym zapleczu „Kazania przy przyjmowaniu świątości małżeństwa” Józefa Wereszczyńskiego. Ślaskie Studia Polonistyczne, 14 (2), 279-292.

Winiarska-Górska, I. (2015). Staropolskie ewangelickie katechizmy i kancjonały jako książki formacyjne. W: D. Chemperek (red.), Ewangelicyzm reformowany w Pierwszej Rzeczypospolitej. Dialog z Europa i wybory aksjologiczne w świetle literatury i piśmiennictwa XVI-XVII wieku (s. 133-169). Warszawa: Wydawnictwa Uniwersytetu Warszawskiego.

Wojtkowska-Maksymik, M. (2008). Miłość i kobieta w przestrzeni dworu w „Il Libro del Cortigiano” (1528) Baldassarra Castiglionego oraz „Dworzaninie polskim” (1566) Łukasza Górnickiego. W: R. Krzywy (red.), Amor vincit omnia. Erotyzm w literaturze staropolskiej (s. 85-100). Warszawa: Wydawnictwa Uniwersytetu Warszawskiego.

Wyrobisz, A. (1992). Staropolskie wzorce rodziny i kobiety - żony i matki. Przegląd Historyczny, 83 (3), 405-421.

\section{The supradenominational nature of the "Marriage treaty" by Jan Płoczywłos Mrowiński}

\section{Summary}

The treaty of Jan Płoczywłos Mrowiński, who signed himself as the burgher of Kazimierz city and a nobleman, was published in 1561 and has an eclectic, confessional profile. The author reflects on marriage using both Catholic and Protestant sources, including the Greater Catechism of Martin Luther or the anonymous (attributed to Stanisław Murzynowski) treatise "Oeconomia, albo Gospodarstwo" (1545), which was a translation of the treatise by Justus Menius. However, unlike the Lutheran texts, this treatise is not a formation book. The author of the sketch proves that the appreciation of eroticism, the approval of two-faith marriages and the shaky stance on divorce presented in the "Stadło małżeńskie" testify to Płoczywłos’s intention to adopt selected reformers' proposals to the Catholic ground. This means that the compilation piece is intended to introduce elements of a Protestant approach to marriages on a Catholic basis.

Słowa kluczowe: Jan Płoczywłos Mrowiński, Justus Menius, małżeństwo, protestantyzm, katolicyzm, renesans Keywords: Jan Płoczywłos Mrowiński, Justus Menius, marriage, Protestantism, Catholicism, Renaissance 
http://rcin.org.pl 